\title{
On the streets at the G20
}

Published at www.cmaj.ca on Aug. 13

$\mathrm{W}$ e awoke with a combination of anticipation and apprehension. It was Saturday, June 26, the first day the Group of 20 - an association of the world's major economic powers - would be meeting in Toronto, Ontario. The city had already seen a week of demonstrations and rallies promoting awareness of the negative impact of $\mathrm{G} 20$ policies on the environment, on migration, on indigenous peoples and on other communities. The crowds included a few people handing out water and sunblock. We were among those "street medics," who had come together to provide preventive and first-aid care to protesters.

This was not an apolitical act. For most of us, it sprang from a desire to support healthy dissent. In our daily work, we often advocate for people whose health is determined largely by their social conditions. At a broader level, many of us see the G20 as an unhealthy institution whose decisions contribute to poor health outcomes for marginalized populations both locally and globally. Being on the streets as "medics" was one way of engaging with these larger problems.

During the previous days we had already heard of several disturbing incidents. At least one of our fellow medics had seen a pepper-spray injury. Another had sent someone to hospital with blurred vision and a possible concussion from several punches to the head by the police. Several medics had been stopped during the many police searches across the city and their supplies had been confiscated.

Later Saturday morning we met with colleagues to fill our backpacks with sunblock, water bottles, gauze and cold packs. We were not sure what to expect and planned to stick to first aid

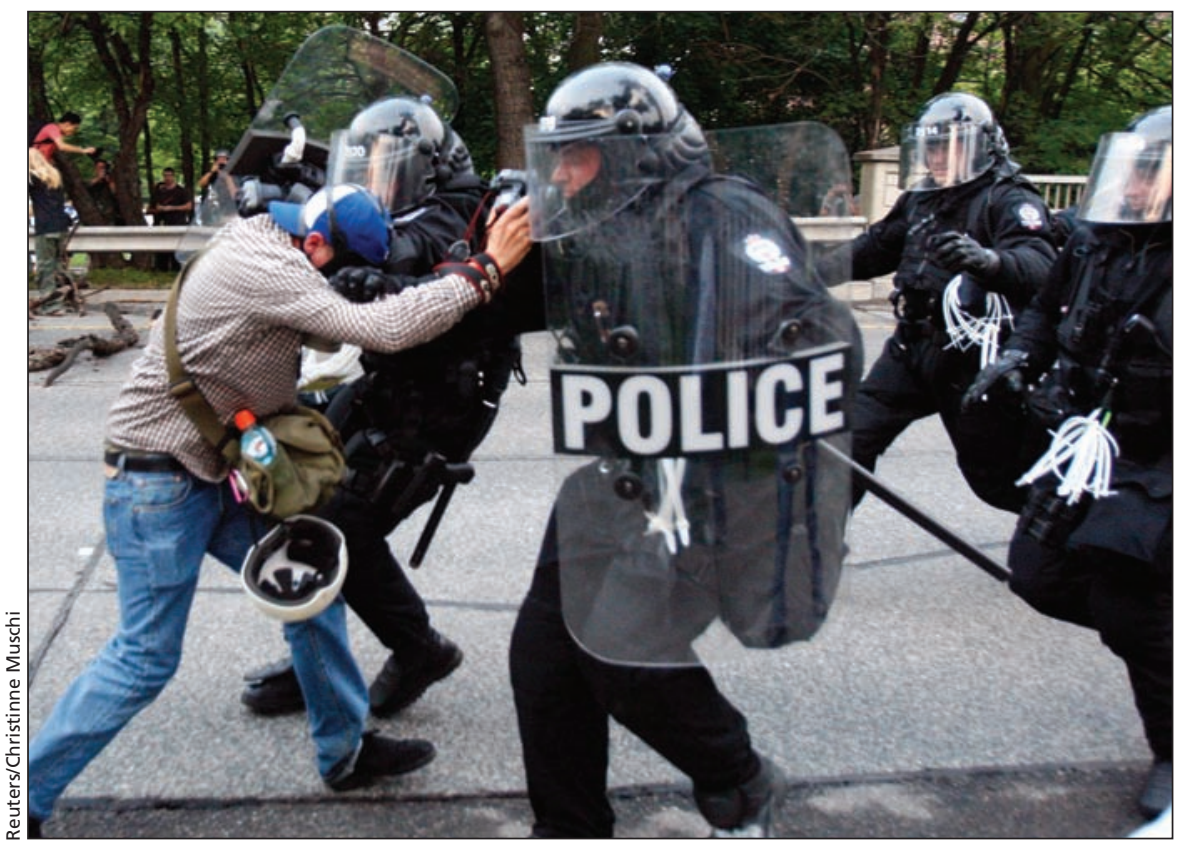

Police officers clash with a protester during a demonstration at the G20 summit in Toronto, Ontario, on June 26.

only. As we set off, we tried not to draw too much attention to ourselves. It felt ridiculous to worry, until we saw swarms of police surrounding and searching people who had been walking peacefully. We continued silently, our nerves on edge.

We arrived at Queen's Park, in front of the Ontario legislature, just as a major march was beginning. Despite the rows of police lining the protest route, many wearing helmets and carrying riot shields, the mood was jubilant and energetic. Our senses were flooded with noise and colour. There were samba beats in the air, banners critiquing the approach to maternal health in foreign aid policy, and creative artistic displays about political prisoners. It was an inspiring mix of communities rallying together.

Soon, however, we saw areas of growing confrontation. Our cellphones started ringing as medics began report- ing injuries. One medic went to the emergency department with a young woman who was vomiting on the street after being hit on the head by police. She then saw another woman with what was later confirmed to be a broken finger from a baton strike. A group of medics farther downtown was splinting what appeared to be a classic forearm "nightstick" fracture. Yet another pair of medics, surrounded by police, was trying to get help for a young man with a baton injury to the head. He was bleeding profusely and had a lowered level of consciousness. No one could get to them, including Emergency Medical Services, so the medics eventually placed him on a sandwich board and recruited a vegetable truck to transport him to an ambulance.

We didn't ask whether the people we assisted were "bystanders" or "protesters," "provocative" or "peaceful" — the distinctions didn't matter to us. 
They had all suffered injuries that were either reported to or directly witnessed by medics as being the result of police action.

Feeling tired, we agreed to regroup at Queen's Park after the march. As we walked up Yonge Street, normally one of Toronto's busiest shopping areas, we saw a number of damaged storefronts. We wondered if these broken windows would be used to justify the intense police surveillance and injuries - the broken bones - that we had seen earlier that day.

When we returned to Queen's Park, the setting had noticeably altered. There were police everywhere, plus a somewhat subdued mix of resting protesters and bewildered passersby. We sat on the grass, sharing water and snacks. Suddenly a line of riot police charged at us, kicking and striking with batons at seated protesters, pepper-spraying as they went. It was happening too quickly to understand. We scrambled to our feet, and people spilled, screaming, into the street. We pulled people away from the advancing police and doused their burning eyes with water, reassured them until the pain and blindness began to fade, and made sure they had somewhere safe to go.

The day ended with many of us struggling to make sense of what we had seen.

The next day included more assembling, more protests and more violent dispersal of demonstrators. People were seemingly arrested at random and many were detained. Once the G20 had concluded and most police had left town, we thought our task was over.
As detainees began to be released, however, we received alarmed calls from other medics to "come right away." Some people had been released without ID or money, and were being brought to a safe space. They spoke of having been handcuffed for hours unable to go to a toilet, of water deprivation, of floors so cold that they were unable to fall asleep, and of being denied their medications. One medic gave warm tea and blankets to a shaking and tearful older man who had missed several doses of his psychiatric medications. Another met a young person with type 1 diabetes from out of town who had been released without his insulin, health card or money, and had not eaten that day for fear of hyperglycemia. We worked into the night, trying to obtain medications for people. These were not isolated stories but rather formed a narrative of infringement of rights that had become all too familiar.

It was difficult to go back to work after this - after the surveillance and searches, the outright violence we had witnessed and the stories from detention. Some people spoke in outraged tones about the property damage highlighted by the media, but we couldn't let those images somehow replace ours, as if multiple truths couldn't exist together. These few days had shaken a worldview that some of us didn't even realize we had. Many of us have enjoyed a fundamental sense of security since childhood, and are so used to our safety that we can't understand life without it. The weekend gave us a brief, visceral glimpse of the reality of many people - especially those from certain targeted groups who suffer the abuse of institutional power every day.

We found it troubling to watch the news in the aftermath, with its almost complete lack of commentary on the decisions made in Toronto by the G20. Their proposed "austerity measures" will have a lasting detrimental impact on the health of many local and international communities. The events of June 25-27 were disturbing, and have left us shaken. But by focusing exclusively on the physical violence of the moment, we risk forgetting the economic violence experienced by so many who are marginalized by society. We risk forgetting the very reasons that people came together to protest the G20 in the first place.

It has now been a few weeks since these experiences on the streets of Toronto. Our response must start with what we've seen - the police conduct and its health impacts - as we join the call for an inquiry to be fully independent and receive broad public testimonials to ensure accountability. Much more than this, however, needs to change. We must continue to act together, as physicians and members of a global community, in the belief that health for all people is both a fundamental right and an essential component of social justice. - Priya Raju, MD, and Michaela Beder, MD, Toronto, Ont.

DOI:10.1503/cmaj.109-3338 